\title{
Characterization and Potential Applications of Heterotrophic Bacteria Inhabit Nickel Rich Soils in Çanakkale, Turkey*
}

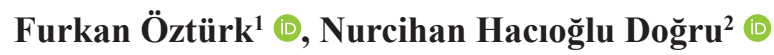

\begin{abstract}
*Part of the research was presented at the Çanakkale Onsekiz Mart University 1st International Symposium on Biodiversity Research (May 2-4, 2019).

${ }^{1}$ Çanakkale Onsekiz Mart University, Faculty of Arts and Sciences, Department of Biology, Çanakkale, Turkey
\end{abstract}

ORCID: F.Ö. 0000-0002-9752-0584; N.H.D. 0000-0002-5812-9398

Received: 28.02 .2020

Revision Requested: 29.02.2020

Last Revision Received: 08.03.2020

Accepted: 09.03.2020

Correspondence: Nurcihan Hacioğlu Doğru nurcihan.n@gmail.com

Citation: Öztürk, F., \& Hacıoğlu-Doğru, N. (2020). Characterization and Potential Applications of Heterotrophic Bacteria Inhabit Nickel Rich Soils in Çanakkale, Turkey. Turkish Journal of Bioscience and Collections, 4(1), 7-13.

https://doi.org/10.26650/tjbc.20200014

\begin{abstract}
Microorganisms inhabit extreme environments such as high nickel rich soils are novel in terms of diversity and also valuable source of extracellular hydrolytic enzymes. The present study focused on isolation and characterization of heterotrophic bacteria from Nickel rich soils in Çanakkale, using culture dependent method and assessment of their heavy metal, antibiotic resistance and potential for production of some industrially important enzymes. Total 35 bacterial isolates were characterized morphologically, biochemically and these analysis of strains revealed that these strains were able to grow between $4-50{ }^{\circ} \mathrm{C}$. These isolates also showed high heavy metal and antibiotic resistance and ability to produce one or more extracellular enzymes like amylase, protease, lipase and DNAse. Thus, the isolates from Ezine, Çanakkale could be potential candidates for industrial applications.
\end{abstract}

Keywords: Soil bacteria, Nickel, Heavy metal, Antimicrobial sensivity, Enzymatic activity

important toxic heavy metals (EPA, 2002). In addition, nickel is considered to be one of the 25 important compounds which are poisonous to human health.

Ni-containing plants are called high-level metal accumulators (hyper accumulators). This term represents a concentration 100 times higher than the maximum expected for non-accumulating species grown in serpentines (Brooks, 2000). More than half Alyssum taxa of the Flora of Turkey, has high levels of heavy metal accumulation properties. Some of the regions in the Ezine district of Çanakkale are very important areas for the development of 
the Alyssum pinifolium (Nyar, T.R. Dudley) plant. As a result of the soil analyzes performed by Esen (2016), the structure of the soil of the Ezine Road is fertile, the salinity $0.33 \mathrm{dS} / \mathrm{m}$ (without salt), the $\mathrm{pH} 7.52$ (slightly alkaline), the lime $0.81 \%$ (low), the organic matter $0.85 \%$. (low), phosphorus $3.99 \mathrm{~kg} / \mathrm{da}$ (low), potassium $13.95 \mathrm{~kg} / \mathrm{da}$ (low), calcium 810 ppm (low), magnesium 619 ppm (medium), sodium 399 ppm (high), iron 7.62 ppm (very high), copper $0.22 \mathrm{ppm}$ (low), manganese $5.44 \mathrm{ppm}$ (medium), zinc 0.17 ppm (low), and nickel $1702 \mathrm{mg} / \mathrm{g}$ (very high) was determined. In addition, the amount of nickel collected in the plant samples obtained from the A. pinifolium distribution areas was analyzed: $1781 \mathrm{mg} / \mathrm{g}$ in the Ezine road population (Esen, 2016).

It is possible to develop new technologies from these adapted organisms by reducing the amount of nickel in soil and water, especially by understanding the metabolic activities of nickel-related microorganisms. Therefore, it is important to know the microbial diversity in these areas. In this study, it was aimed to determine the bacterial diversity in nickelcontaining A. pinifolium soils and to determine some biochemical properties, environmental requirements and antibiotic-heavy metal resistance and enzymatic activities of isolates that could be used in possible Ni bioremediation.

\section{Material and Methods}

\section{Site description and sample collection}

The region which covers about $3208 \mathrm{~m}^{2}$ and found species of A. pinifolium in slope with serpentine soil $\left(39^{\circ} 52^{\prime} \mathrm{N}\right.$ and $26^{\circ} 19^{\prime} \mathrm{E}$ ) by the highway where locate $6 \mathrm{~km}$ North away from Ezine district of Çanakkale province (Table 1). Appointed soil samples were collected from $10 \mathrm{~cm}$ depth of soil surface with the help of sterile spatula from different five locations that $A$. pinifolium exists and transferred into sterilized polythene bags and transported aseptically to laboratory.

\section{Isolation and purification of bacterial isolates}

$10 \mathrm{~g}$ of collected soil samples were suspended in $90 \mathrm{~g}$ distilled water $0.90 \%$ and the suspension were made $10^{-5}$ fold serial dilution. $100 \mu \mathrm{L}$ of each fold was transferred to appropriate growth medium. Nutrient Agar and Tryptic Soya Agar were used for bacterial isolation. The plates were incubated at $35 \pm 2^{\circ} \mathrm{C}$ for $24 \mathrm{~h}$ (Tamer et al., 1989). The colonies grown on the plates were purified by successive streaking on nutrient agar plates. Isolated bacterial strains were then stored at $4^{\circ} \mathrm{C}$ in refrigerator for further study.

\section{Biochemical characterization}

The pure cultures were obtained. The appearance of colony such as shape, color was observed by magnifying lens (10X) with the simple strain technique after the growth of isolated strains. Gram staining process was performed according to the method determined by Bozkurt (2016). A series of basic biochemical tests were performed with oxidase, catalase, indole, citrate, voges proskauer (VP), methyl red (MR) test and Kilger's iron agar (KIA) test (Tamer et al., 1989).

\section{Determination of physiological growth characteristics of isolates}

Isolates transferred to calibrated medium for determining the appropriate growth requirement such as $\mathrm{pH}$, temperature, salt, using carbon resource by using culture dependent method as described previously by Bozkurt (2016). The effect of $\mathrm{pH}$ on growth of isolates was tested with the $\mathrm{pH}$ range from 5.0 to 11.0. The temperature range for optimum growth was determined by incubating the isolates from 4 to $50^{\circ} \mathrm{C}$ (Bozkurt, 2016). The effect of the salt on growth of isolates was tested with the salt range from 2.0 to $23.0 \%$ (Karaboz \& Ozcan, 2005).

Table 1. Location, altitude and coordinates of soil samples.

\begin{tabular}{|c|c|c|c|}
\hline Samples & Location & Altitude & Coordinates \\
\hline \multirow{2}{*}{ I } & Ezine/Çanakkale & \multirow{2}{*}{$111 \mathrm{~m}$} & $39.873416 \mathrm{~N}$ \\
\hline & (Near of Araplar strait) & & $26.323919 \mathrm{E}$ \\
\hline \multirow{2}{*}{ II } & \multirow{2}{*}{ Sarımsaklı bridge, Kendirlik site } & \multirow{2}{*}{$55 \mathrm{~m}$} & $39.840276 \mathrm{~N}$ \\
\hline & & & $26.320107 \mathrm{E}$ \\
\hline \multirow{2}{*}{ III } & \multirow{2}{*}{ Araplar strait, Ahlatlı site } & \multirow{2}{*}{$50 \mathrm{~m}$} & $39.853860 \mathrm{~N}$ \\
\hline & & & $26.318425 \mathrm{E}$ \\
\hline \multirow{2}{*}{ IV } & \multirow{2}{*}{ Menderes Mountain } & \multirow{2}{*}{$273 \mathrm{~m}$} & $39.960355 \mathrm{~N}$ \\
\hline & & & $26.374708 \mathrm{E}$ \\
\hline \multirow{2}{*}{$\mathbf{V}$} & \multirow{2}{*}{ Ovacık, Küçük Uludağ } & \multirow{2}{*}{$423 \mathrm{~m}$} & $39.982499 \mathrm{~N}$ \\
\hline & & & $26.416317 \mathrm{E}$ \\
\hline
\end{tabular}




\section{Antibiotic sensitivity testing}

Susceptibility testing was performed by an agar diffusion method (Bauer et al., 1966), using Mueller-Hinton Agar (Oxoid) and 15 antibiotic discs: Sulfamethoxazole (SMZ100), Oxytetracycline (T30), Cephotaxime (CE30), Cefoxitin (CN30), Trimethaprim (TR10), Cephalothin (CH30), Chloramphenicol (C30), Kanamycin (K30), Furazolidone (FR50), Cefmetazole (CMZ30), Tobramycin (TB10), Erythromycin (E15), Ampicillin (A10), Gentamicin (G120), Amoxicillin (AX25). The isolates were determined to be sensitive to antibiotics according to the information supplied by the manufacturer (NCCLS, 2007). Reference strain of Escherichia coli ATCC 11230, were used as control organisms for verification of the antibacterial effect of the discs.

\section{Determination of the MIC of heavy metals}

The minimal inhibitory concentration (MIC) for each bacterial isolate for seven heavy metals was determined by using Mueller-Hinton Agar which is containing $\mathrm{Cd}^{2+}$, $\mathrm{Cr}^{3+}, \mathrm{Cu}^{2+}, \mathrm{Ni}^{2+}, \mathrm{Mn}^{2+}, \mathrm{Pb}^{2+}$, and $\mathrm{Zn}^{2+}$ at concentrations ranging from 100 to $12800 \mu \mathrm{g} / \mathrm{mL}$. The metals were added as $\mathrm{CdCl}_{2} .2 \mathrm{H}_{2} \mathrm{O}, \mathrm{K}_{2} \mathrm{Cr}_{2} \mathrm{O}_{7}, \mathrm{CuSO}_{4} 5 \mathrm{H}_{2} \mathrm{O}, \mathrm{Ni}(\mathrm{CO})_{4}$, $\mathrm{MnCl}_{2} \cdot 2 \mathrm{H}_{2} \mathrm{O}, \mathrm{Pb}\left(\mathrm{NO}_{3}\right)_{2}$ and $\mathrm{ZnCl}_{2}$. The isolates were considered resistant if the MIC values exceeded that of the E. coli K-12 strain which was used as the control (Matyar et al., 2008).

\section{Screening of isolates for extracellular hydrolytic activities}

All isolates were examined for their enzyme activity like DNase, lipase, protease and amylase by using standard methods (Sokol et al., 1979; Collins et al., 1989; Collins et al., 2003).

\section{Results}

A total of 35 bacteria were isolated from five stations soil samples. According to Gram staining reaction, 31 Gram positive and 4 Gram negative, rod shaped isolates were determined. 34 bacteria have endospore structure; 5 bacteria were found to be oxidase positive and 14 bacteria to be catalase positive. All to bacteria were found give results for indole test $(+/-), 15$ bacteria citrate tests were positive, 24 bacteria were tested for methyl red positive and 29 bacteria were tested for VP test positive (Table 2).

All isolates showed optimum growth in the temperature range of $20-37^{\circ} \mathrm{C}$. 20 isolates at $4{ }^{\circ} \mathrm{C} ; 9$ isolates did not grow at $50^{\circ} \mathrm{C}$ (Fig. 1). The optimum $\mathrm{pH}$ range for growth of all strains was observed 5.0 to 11.0 , except $1 \mathrm{~T} 1$ and $3 \mathrm{~T} 13$ (at $\mathrm{pH}$ 9) and 4T30 (at pH 11) (Fig. 1). Isolates growth rate at different salt concentrations was examined; these rates were $100 \%, 80 \%, 25.71 \%, 31.42 \%$ at the salt concentration of $2 \%, 6 \%, 12 \%, 18 \%$, respectively. There was no growth at the salt concentration of $23 \%$ (Fig. 2).

It was found that most effective antibiotic was G120 and about $94.28,85.71,82.85$ and $80 \%$ of the isolates were resistant to $\mathrm{CN} 30, \mathrm{~A} 10, \mathrm{~T} 30$ and CMZ30, respectively (Fig. 3).

Results of heavy metal resistance of isolates were shown in Figure 4. The highest concentration of $\mathrm{Cd}^{2+}$, $\mathrm{Cr}^{3+}, \mathrm{Cu}^{2+}, \mathrm{Ni}^{2+}, \mathrm{Mn}^{2+}, \mathrm{Pb}^{2+}, \mathrm{Zn}^{2+}$ metals which observe the bacteria growth are $40 \%, 17.14 \%, 17.14 \%, 17.14 \%$, $31.42 \%, 8.57 \%, 20 \%$, respectively.

The isolates were tested for their ability to produce four industrially important hydrolytic enzymes (Table 3). Interestingly, it was noted that except $5 \mathrm{~N} 12$ and $3 \mathrm{~N} 2$, all other strains showed multi hydrolytic enzyme production ability. 28 isolates showed the ability to produce also 4 enzymes. 5 bacteria showed the ability to produce 3 enzymes and 2 bacteria just showed the ability to produce 1 enzyme (Table 3 ).

\section{Discussion}

Nowadays, the increasing industrialization rate in the world is threatening for the quality of abiotic resource such as soil, water and atmosphere. Contaminating of ecosystem and the amount of toxic and dangerous substance has been increased by using of industrial activities and the application of various chemicals (Eghomwanre et al., 2016). Toxic metals, including extremely basic metals, disrupt their biological structures and systems into reversible or irreversible compatibility, leading to the impaired organ function or ultimate death. The environment contains less amount of $\mathrm{Ni}$ which known heavy metal. Environmental pollution increase day by day because of the using of vast industrial of nickel containing material production includes recycling and disposal of them. By $\mathrm{Ni}$ mining or by various industrial processes, power plants or incinerators, rubber and plastic industries, nickel-cadmium battery industries and electroplating industries are caused of charging of $\mathrm{Ni}$ into the atmosphere. The widespread using or occupational exposure of $\mathrm{Ni}$ in various industries is definitely a matter of serious impact on human health.

There are many studies where new isolates with different isolates and conditions are adapted to different soils, such as 
Table 2. Morphological features and biochemical characteristic of isolates (+: positive; -: negative; $\mathrm{Y}=$ yellow (acid), $\mathrm{P}=$ pink (alkaline), Black $=\mathrm{H}_{2} \mathrm{~S}$ )

\begin{tabular}{|c|c|c|c|c|c|c|c|c|c|c|c|c|c|}
\hline \multirow{3}{*}{ Station } & \multirow{3}{*}{ Isolate } & \multicolumn{12}{|c|}{ Characteristics } \\
\hline & & \multirow{2}{*}{$\begin{array}{c}\text { Gram } \\
\text { staining }\end{array}$} & \multirow{2}{*}{ Shape } & \multirow{2}{*}{ Endospore } & \multirow{2}{*}{ Oxidase } & \multirow{2}{*}{ Catalase } & \multirow{2}{*}{ Indole } & \multirow{2}{*}{ Citrate } & \multicolumn{3}{|c|}{ KIA } & \multirow{2}{*}{ MR } & \multirow{2}{*}{ VP } \\
\hline & & & & & & & & & Slant & Butt & Gas & & \\
\hline \multirow{7}{*}{ - } & 1N4 & + & Rod & + & - & - & $+/-$ & - & alkaline & acid & - & + & - \\
\hline & $1 \mathrm{N5}$ & + & Rod & + & - & + & $+/-$ & - & alkaline & alkaline & - & + & + \\
\hline & $1 N 7$ & - & Rod & + & - & + & $+/-$ & + & alkaline & acid & - & + & + \\
\hline & $1 \mathrm{~N} 18$ & + & Rod & - & + & + & $+/-$ & + & alkaline & acid & - & + & + \\
\hline & $1 \mathrm{T1}$ & + & Rod & + & - & + & $+/-$ & - & alkaline & acid & - & + & + \\
\hline & $1 \mathrm{~T} 2$ & + & Rod & + & + & - & $+/-$ & - & alkaline & alkaline & - & + & + \\
\hline & $1 T 3$ & + & Rod & + & - & - & $+/-$ & - & alkaline & acid & - & + & + \\
\hline \multirow{5}{*}{$=$} & 2N15 & - & Rod & + & - & + & $+/-$ & + & alkaline & acid & - & + & + \\
\hline & 2N19 & + & Rod & + & - & - & $+/-$ & - & alkaline & alkaline & - & + & + \\
\hline & $2 \mathrm{~T} 4$ & + & Rod & + & - & + & $+/-$ & + & alkaline & acid & - & - & - \\
\hline & $2 \mathrm{~T} 6$ & + & Rod & + & - & + & $+/-$ & - & alkaline & alkaline & - & + & + \\
\hline & $2 \mathrm{~T} 24$ & + & Rod & + & - & - & $+/-$ & + & alkaline & acid & - & - & + \\
\hline \multirow{6}{*}{ 三 } & 3N1 & + & Rod & + & - & + & $+/-$ & - & alkaline & acid & - & + & + \\
\hline & $3 N 2$ & - & Rod & + & - & + & $+/-$ & + & alkaline & acid & - & + & + \\
\hline & $3 N 3$ & + & Rod & + & + & - & $+/-$ & - & alkaline & alkaline & - & - & + \\
\hline & $3 N 17$ & + & Rod & + & + & - & $+/-$ & - & alkaline & acid & - & - & - \\
\hline & $3 \mathrm{~T} 13$ & - & Rod & + & - & - & $+/-$ & + & alkaline & alkaline & - & + & - \\
\hline & $3 \mathrm{~T} 14$ & + & Rod & + & - & - & $+/-$ & + & alkaline & alkaline & - & + & + \\
\hline \multirow{9}{*}{ Z } & 4N9 & + & Rod & + & - & - & $+/-$ & + & acid & alkaline & - & + & + \\
\hline & $4 \mathrm{~T} 9$ & + & Rod & + & - & + & $+/-$ & - & acid & acid & - & + & - \\
\hline & $4 \mathrm{~T} 10$ & + & Rod & + & - & - & $+/-$ & - & alkaline & acid & - & - & + \\
\hline & $4 \mathrm{~T} 12$ & + & Rod & + & - & + & $+/-$ & - & alkaline & acid & - & + & - \\
\hline & $4 T 26$ & + & Rod & + & - & - & $+/-$ & + & alkaline & acid & - & + & + \\
\hline & $4 \mathrm{~T} 27$ & + & Rod & + & - & + & $+/-$ & - & alkaline & alkaline & - & - & - \\
\hline & $4 T 30$ & + & Rod & + & - & - & $+/-$ & + & alkaline & acid & - & + & + \\
\hline & $4 T 31$ & + & Rod & + & + & - & $+/-$ & + & alkaline & alkaline & - & - & - \\
\hline & $4 T 32$ & + & Rod & + & - & + & $+/-$ & - & alkaline & alkaline & - & - & - \\
\hline \multirow{8}{*}{$>$} & $5 \mathrm{~N} 12$ & + & Rod & + & - & + & $+/-$ & - & alkaline & acid & - & - & - \\
\hline & $5 \mathrm{N13}$ & - & Rod & + & & & $+/-$ & - & alkaline & acid & - & - & - \\
\hline & $5 \mathrm{~N} 14$ & + & Rod & + & - & - & $+/-$ & - & alkaline & acid & - & + & + \\
\hline & $5 T 15$ & + & Rod & + & - & - & $+/-$ & + & alkaline & acid & - & - & - \\
\hline & $5 \mathrm{~T} 17$ & + & Rod & + & - & - & $+/-$ & - & alkaline & alkaline & - & + & + \\
\hline & $5 T 19$ & + & Rod & + & - & - & $+/-$ & - & alkaline & acid & - & + & - \\
\hline & $5 T 20$ & + & Rod & + & - & - & $+/-$ & + & alkaline & alkaline & - & + & - \\
\hline & $5 T 28$ & + & Rod & + & - & - & $+/-$ & + & alkaline & acid & - & + & - \\
\hline
\end{tabular}

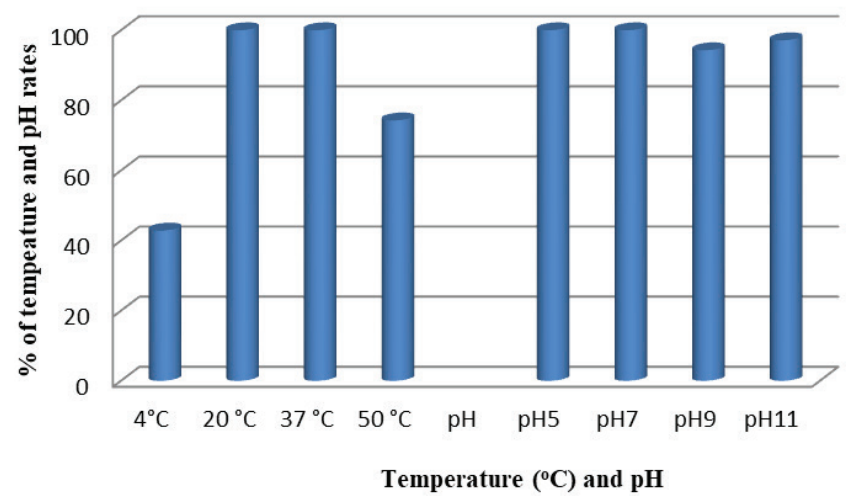

Figure 1. Percent of temperature and $\mathrm{pH}$ growth range of isolated soil bacteria.

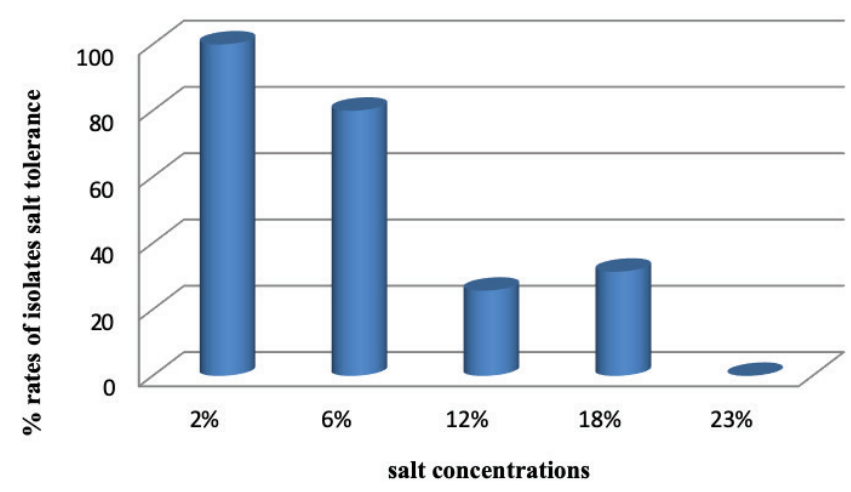

Figure 2. Percent of salt tolerance of isolated soil bacteria. 


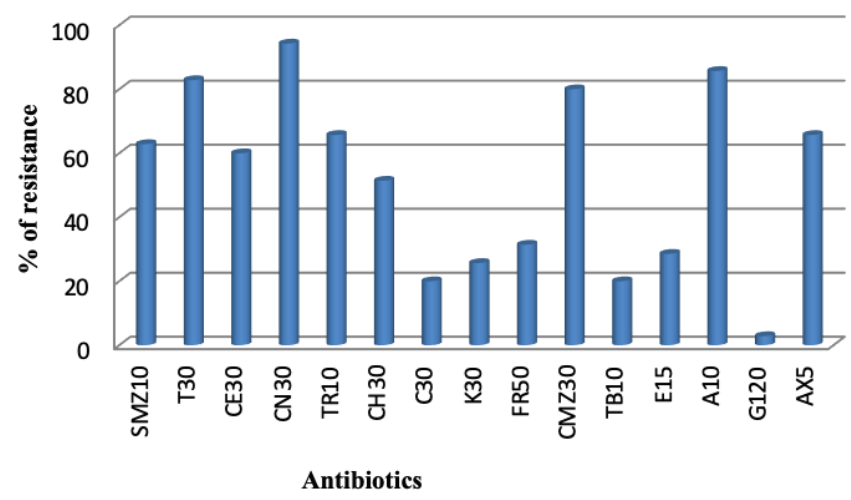

Figure 3. Percent of antibiotic resistance against isolated soil bacteria. heavy metal chemicals or extreme physical conditions (Gülcan, 2006; Sevgi, 2007; Saraç et al., 2008; Dülger, 2012; Eghomwanre et al., 2016; Neelam et al., 2018).

Neha et al. (2015) isolated and identified heavy metal resistant bacteria from petroleum soil of Loni and found that the strains showed diverse metabolic pattern of carbon sources and other growth factors. They also showed tolerance to other heavy metals, such as copper, lead and nickel.

Eghomwanre et al. (2016) researched some selected bacteria that are from contaminated soils and sediments around Warri area of Delta State, for the tolerances of antibiotic resistance patterns and heavy metals such as $\mathrm{Pb}, \mathrm{Zn}, \mathrm{Cd}$ and $\mathrm{Fe}$. The most resistant isolates were

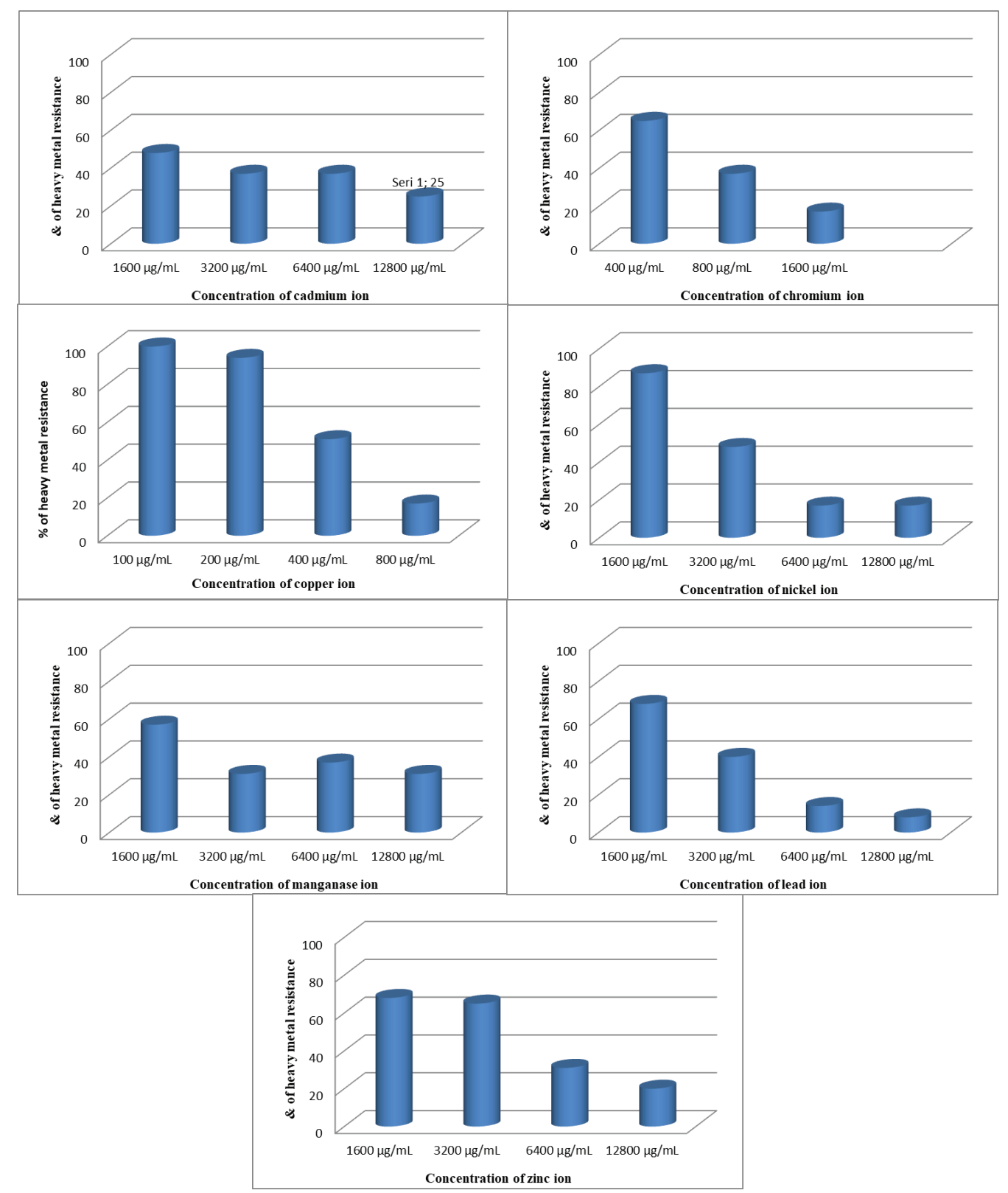

Figure 4. Percent of heavy metal resistance of isolated soil bacteria. 
Table 3. Screening of industrially putative enzymes from isolated soil bacteria (+: positive; -: negative)

\begin{tabular}{|c|c|c|c|c|}
\hline Isolates no & DNAse & Lipase & Protease & Amylase \\
\hline $1 \mathrm{~N} 4$ & + & + & + & + \\
\hline $1 N 5$ & + & + & - & + \\
\hline $1 \mathrm{~N} 7$ & + & + & + & + \\
\hline 1N18 & + & + & + & + \\
\hline 1T1 & - & + & + & + \\
\hline $1 T 2$ & + & + & + & + \\
\hline $1 T 3$ & + & + & + & + \\
\hline $2 N 15$ & + & + & + & + \\
\hline 2N19 & + & + & + & + \\
\hline $2 \mathrm{~T} 4$ & + & + & + & + \\
\hline $2 \mathrm{~T} 6$ & + & + & + & + \\
\hline $2 \mathrm{~T} 24$ & - & + & + & + \\
\hline 3N1 & + & + & + & + \\
\hline $3 \mathrm{~N} 2$ & - & - & - & + \\
\hline $3 N 3$ & + & + & + & + \\
\hline 3N17 & + & + & + & + \\
\hline $3 \mathrm{~T} 13$ & + & + & + & + \\
\hline $3 \mathrm{~T} 14$ & + & + & + & + \\
\hline 4N9 & + & + & + & + \\
\hline $4 \mathrm{T9}$ & + & + & + & + \\
\hline $4 \mathrm{~T} 10$ & + & + & + & + \\
\hline $4 \mathrm{~T} 12$ & + & + & + & + \\
\hline $4 T 26$ & + & + & + & + \\
\hline $4 T 27$ & + & + & + & + \\
\hline 4T30 & - & + & + & + \\
\hline $4 T 31$ & + & + & + & + \\
\hline $4 T 32$ & + & + & + & + \\
\hline $5 \mathrm{~N} 12$ & - & - & - & + \\
\hline $5 N 13$ & - & + & + & + \\
\hline $5 N 14$ & + & + & + & + \\
\hline $5 T 15$ & + & + & + & + \\
\hline $5 \mathrm{T17}$ & + & + & + & + \\
\hline $5 T 19$ & + & + & + & + \\
\hline $5 T 20$ & + & + & + & + \\
\hline $5 T 28$ & + & + & + & + \\
\hline
\end{tabular}

Staphylococcus aureus, Escherichia coli and Pseudomonas aeruginosa from the experiment of multiple drug resistance on the bacterial isolates; while Klebsiella mobilis exhibited the least resistance. At different concentrations of $\mathrm{Pb}$ and $\mathrm{Cd}$, all the bacterial isolates exhibited various degree of sensitivity; meanwhile the organisms showed abundant and moderate growth in the $\mathrm{Fe}$ and $\mathrm{Zn}$ even at higher concentrations. Our results show similarities with these studies. In the present study high degree of heavy metals resistance associated with multiple heavy metals was detected in $\mathrm{Ni}$ rich soil bacteria. These metal resistant bacteria can be utilized in bioremediation of metal contaminated environments. In addition to heavy metal resistance, our isolates have high antibiotic resistance and enzymatic activity. Inimitableness and characteristics of them could be used as agents of potential bioremediation for taking out the heavy metals from the environment and source of industrial enzymes. More studies are required to assess the heavy metal extraction ability of those isolates.

Peer-review: Externally peer-reviewed.

Author Contributions: Conception/Design of study: F. Ö.; Data Acquisition: F. Ö., N. H. D.; Data Analysis/ Interpretation: N. H. D.; Drafting Manuscript: F. Ö., N. H. D.; Critical Revision of Manuscript: N. H. D.; Final Approval and Accountability: F. Ö., N. H. D.; Technical or Material Support: F. Ö., N. H. D.; Supervision: . H. D.

Conflict of Interest: The authors declare that they have no conflicts of interest.

Financial Disclosure: The present study was supported by the TÜBİTAK (Project no: 2209 A).

\section{References}

Alexander, M. (1961). Introduction to Soil Microbiology. 2nd ed. (New York, USA): John Wiley and Sons Inc. ISBN 9780471021780

Bauer, A. W., Kirby, W. M. M., Sherris, J. C., \& Turck, M. (1966). Antibiotic Susceptibility Testing by a Standardized Single Disk Method. American Journal of Clinical Pathology, 45(4 ts), 493-496. https://doi.org/10.1093/ajcp/45.4_ts.493.

Brooks, R. R (1998). Plants that hyperaccumulate heavy metals: their role in phytoremediation microbiology, archaeology, mineral exploration and phytomining, CAB International, Oxford: New York.

Bozkurt, D. (2016). Bor İçeren Ortamlarda Prokaryotik Çeşitliliğin Belirlenmesi. Eskişehir Osmangazi Üniversitesi Fen Bilimleri Enstitüsü. (Master Thesis).

Collins, M. D., Phillips, B. A., \& Zanoni, P. (1989). Deoxyribonucleic acid homology studies of Lactobacillus casei, Lactobacillus paracasei sp. nov., subsp. paracasei and subsp. tolerans, and Lactobacillus rhamnosus sp. nov., comb. nov. International Journal of Systematic Bacteriology, 39 (2), 105-108. https://doi. org/10.1099/00207713-39-2-105.

Collins, Y. F., McSweeney, P. L. H., \& Wilkinson, M. G. (2003). Lipolysis and free fatty acid catabolism in cheese: A review of current knowledge. International Dairy Journal. 13(11), 841-866. https://doi.org/10.1016/S09586946(03)00109-2.

Das, K.K., Reddy, R.C., Bagoji, I.B., Das, S., Bagali, S., Mullur, L., Khodnapur, J.P. \& Biradar, M.S. (2018). Primary concept of nickel toxicity - an overview. J Basic Clin Physiol Pharmacol. 4;30(2), 141-152. doi: 10.1515/jbcpp-2017-0171. 
Dülger, G. (2012). Termik Santral Bölgesindeki (Çan-Çanakkale) Topraklardan Ağır Metale Karşı Dirençli Bakterilerin İzolasyonu, Tanılanması ve Plazmid Profillerinin Belirlenmesi. Çanakkale Onsekiz Mart Üniversitesi, Fen Bilimleri Enstitüsü, Biyoloji Anabilim Dalı, Çanakkale, s. 107. (PhD Thesis).

Eghomwanre, A.F., Obayagnona, N.O., Osarenotor, O. \& Enagbonma, B.J. (2016). Evaluation of Antibiotic Resistance Patterns and Heavy Metals Tolerance of some Bacteria Isolated from Contaminated Soils and Sediments from Warri, Delta State, Nigeria. J. Appl. Sci. Environ. Manage. 20 (2), 287 - 291. Esen, O. (2016). Endemik Alyssum pinifolium (Nyár.) Dudley ve Dianthus ingoldbyi Turr1l Üzerinde Koruma Biyolojisi Çalışmaları. Canakkale Onsekiz Mart Ünivesitesi, Fen Bilimleri Enstitüsü, Biyoloji Anabilim Dalı. (PhD Thesis).

Environmental Protection Agency (EPA). 2002. Pollution prevention fact sheet ersistent, bioaccumulative and toxic chemicals nickel and nickel compounds. EPA number 96, Ohio, 1-2.

Gülcan, S. (2006). Çeşitli Kaynaklardan İzole Edilen Pseudomonas Türü Bakterilerin Ağır Metal ve Naftalin Toleransı. Pamukkale Üniversitesi, Fen Bilimleri Enstitüsü, Biyoloji Bölümü. (Master Thesis).

Karaboz, İ. \& Ozcan, N.H. (2005). İzmir ve Aydın Yöresindeki Topraklardan İzole Edilen Azotobacter chroococcum Beijerinck 1901 İzolatlarının Tuz Sicaklık ve Bazı Ağır Metallere Toleranslarının Belirlenmesi. Orlab On-Line Mikrobiyoloji Dergisi. 3, 2-10.

Matyar, F., Kaya, A., Dinçer, S. (2008). Antibacterial agents and heavy metal resistance in Gram-negative bacteria isolated from seawater, shrimp and sediment in Iskenderun Bay, Turkey. Sci Total Environ. 15;407(1):279-285. doi: 10.1016/j. scitotenv.2008.08.014.
NCCLS, (2007). Performance Standards for Antimicrobial Susceptibility Testing. In Clinical and Laboratory Standars Institute - NCCLS. https://doi.org/1-56238-525-5

Neelam, D.K., Agrawal, A, Tomer, A.K. \& Dadheech, P.K. (2018). Characterization, Phylogenetic Analysis and Potential Applications of Heterotrophic Bacteria Inhabit Sand Dunes of Thar Desert, India. J Pure Appl Microbiol, 12(4), 1887-1898 http://dx.doi.org/10.22207/JPAM.12.4.24.

Neha, A.G, Korde, V.V., Dhas, S.S. \& Disale M. (2015). Isolation and identification of heavy metal resistant bacteria from petroleum soil of Loni, Ahmednagar. European Journal of Experimental Biology; 5 (12), 6-11.

Özay, C. \& Mammadov, R. (2013). Avaibility of heavy metals and ornamental plants in phytoremediation. Journal of Balıkesir University Institute of Science. 15(1). 67-76.

Saraç, N., Boran, R., Ökmen, G. \& Uğur, A. (2008). Toprak ve Süt Kökenli Gram Pozitif Bakterilerde Lipaz Üretimi. Biyoloji Bilimleri Dergisi, 1(2): 23-28.

Sevgi, E. (2007). Ağır Metalle Kontamine Olmuş Topraklardan Metal İyonlarına Dirençli Bakterilerin İzolasyonu ve Bu Dirençliliğin Plazmidlerle Olan İlişkisinin Araştırılması. Mersin Üniversitesi, Fen Bilimleri Enstitüsü, Biyoloji Anabilim Dal1, Mersin, s. 130. (Master Thesis).

Sokol, P. A., Ohman, D. E., \& Iglewski, B. H. (1979). A more sensitive plate assay for detection of protease production by Pseudomonas aeruginosa. Journal of Clinical Microbiology. 9(4), 538-540.

Tamer, A. Ü., Uçar F., Ünver E., Karaboz İ., Bursalıŏlu M. \& Oğultekin (Eltem) R. (1989). 3. ve 4.Sınıf Mikrobiyoloji laboratuvar kılavuzu, T.C. Anadolu Üniv. Eğitim, Sağlık ve Bilimsel Araş. Çalışmal. Vakfı Yayın., No:74, Eskişehir. 